Karol Tarnowski

\title{
Jean-Luc Marion: teologia w horyzoncie daru
}

„Wyżej od rzeczywistości stoi możliwość”, napisał Heidegger w Sein und Zeit ${ }^{1}$. Zdanie to, które streszcza samo sedno myśli Heideggera, stanowi też poniekąd skrót najgłębszej metodologicznej intuicji fenomenologii. Oznacza ono zasadniczą otwartość fenomenologii, wypływającą z traktowania na serio podstawowego hasła Husserla: „ku samym rzeczom”. „Rzeczy” bowiem, to ani nie facta bruta, ani nie ,przedmioty”, lecz sensy faktów i przedmiotów, tzn. także sposoby, w jaki są dane i prezentują się dla świadomości. Lecz sensy nie są niezmienne: wyłaniają się w obrębie „epistemy” czy „horyzontu”, z którego - w zmieniającym się w ciagu epok dziejowych - przemawiają do nas fakty, wartości i sprawy. Otóż „ojcom fenomenologii”: Husserlowi i Heideggerowi wydawało się, że „horyzont” - pod jakąkolwiek by nie był nazwą - jest ostateczną „rzeczą, do której fenomenolog powinien powrócić, stanowi bowiem ex hypothesi rezerwuar wszystkich dostępnych sensów. Czy tak jest jednak naprawdę? Czy tam, gdzie chodzi o tę ostateczność, jaką jest Absolut, Bóg, nie trzeba postawić pod znakiem zapytania ostateczność horyzontu? Czy nieprzewidziane jeszcze możliwości sensu nie kryją się raczej w samym „daniu” czy prezentowaniu, które stanowi wszak również źródło legitymizacji horyzontu: gdyby horyzont nie był w żaden sposób dany, jakżeby można o nim w ogóle mówić?

${ }^{1}$ M. He i d e g g e r, Bycie i czas, przeł. B. Baran, PWN, Warszawa 1994, s. 54. 
Te bardzo technicznie brzmiące pytania, które stawia najwybitniejszy bodaj żyjący francuski fenomenolog Jean-Luc Marion, są pochodnymi jedynego pytania, jakie go naprawdę obchodzi: o możliwość filozofii Boga po upadku metafizyki. Czym pytanie o konstytuowanie się sensu przedmiotów dla świadomości u Husserla, czym pytanie o sens bycia dla Heideggera, tym dla Mariona jest pytanie o możliwość filozofii naprawdę „,boskiego Boga”, takiego, który by nie był jednym więcej pojęciowym idolem, lecz Bogiem modlitwy i uwielbienia.

Jean-Luc Marion ${ }^{2}$ jest pilnym - może zbyt pilnym - czytelnikiem filozofów, w szczególności zaś fenomenologów z „głównej linii”: Husserla, Heideggera, do pewnego stopnia Levinasa, których włącza do znacznie szerszego filozoficznego spektrum; znajduje się w nim m. in. Kartezjusz (o którym Marion napisał cztery pokaźne dzieła), Nietzsche, Derrida, a przede wszystkim myśl chrześcijańska: Biblia, Pseudo-Dionizy Areopagita, wreszcie bezpośredni mistrz Mariona, teolog Hans Urs von Balthasar. Z perspektywy myśli, a właściwie teologii chrześcijańskiej, Marion toczy nieustannie spór z jednym właściwie filozofem: Heideggerem, toczy go jednak na polu użycia filozoficznych narzędzi fenomenologii, przyczyniając się w ten sposób do pogłębienia problematyki fenomenologicznej jako takiej.

\section{Teoria idola i ikony}

Punktem wyjścia myśli Mariona jest punkt dojścia filozofów poprzedniej, starszej generacji - Heideggera czy Bubera - refleksja nad „zaćmieniem Boga". O ile jednak dla Bubera zaćmienie to wydaje się wiązać z dziedzictwem nietzscheańskim: wolą mocy i z zagubieniem dialogicznego wymiaru religii, dla Heideggera - z tajemnicą zapomnienia o byciu i jego różnicy względem bytu, to dla Mariona ma ono bezpośredni związek z czymś takim, jak, ,idol”. Co to takiego?

2 Jean-Luc Marion, urodzony w 1946 r., absolwent Ecole Normale Supérieure, profesor wielu uniwersytetów francuskich i zagranicznych, ostatnio powołany na Sorbonę, członek wielu komitetów i towarzystw naukowych, a także redakcji (związany początkowo z czasopismem teologicznym „Communio”), kilkakrotnie nagradzany za swoje książki, w 1992 r. Wielką Nagrodą Akademii Francuskiej. Jest autorem kilkunastu książek, z których najważniejsze to: L'idole et la distance (1977), Dieu sans l'être (1982, thum. pol. M. Frankiewicz, Znak, Kraków 1996), Réduction et donation (1989), Prolegomènes à la charité (1986). 
Rozważania nad idolem rozpoczynają się stwierdzeniem faktu, że człowiek ma nieprzepartą skłonność do absolutyzowania swojego kąta patrzenia na rzeczywistość, w szczególności na Boga. Nie tylko każdy metafizyk jest przekonany, że to on właśnie ujął Boga w sposób właściwy, ale - i to jest kluczowe - każdy ateista ma „swojego” Boga, z którym walczy, tzn. swój punkt widzenia na Boga. Jednakże punkt widzenia na Absolut nie może być sam absolutny, jest ,regionalny”, a zatem powinien być zawsze możliwy do rewizji i do postawienia pod znakiem zapytania. W przeciwnym razie zamienia się w idola. Jaka jest „sprężyna” idola, czym jest on w swojej istocie?

Idol jest rezultatem szczególnej, podwójnej intencji ludzkiego podmiotu. $Z$ jednej strony i pierwotnie podmiot dąży, a więc gotów jest do transcendowania tego, co określone, a więc i tego, co widzialne, z drugiej zaś strony powodowany rodzajem „egzystencjalnego zmęczenia” zatrzymuje się na tym, co widzialne i nim nasyca. Jest to możliwe, ponieważ to, co widziane także odpowiada na intencję, tym razem intencję „wzrokową", dążącą do zagarnięcia tego, co oglądane w taki sposób, że wyczerpuje się ono w funkcji bycia oglądanym i staje przez to „na miarę" człowieka. Lecz idol, tak jak go Marion rozumie, nie byłby z kolei możliwy, gdyby jego źródło nie wypływało także z jakiegoś autentycznego doświadczenia boskości. „Idol zwraca nam w twarzy boga nasze doświadczenie boskości. Idol nie przypomina nas, ale boskość, której doświadczamy i którą krystalizuje on w jakiegoś boga po to, byśmy mogli go widzieć. Idol nie zwodzi, lecz zapewnia boskość"3. Jest tak dlatego, że samo doświadczenie wydaje się dwuznaczne: otwierające i zamykające równocześnie. Chce ono - i to jest właśnie funkcją idola - zmniejszać dystans między nami a Bogiem i wytworzyć w Nim pozorną, fałszywą wspólnotę na warunkach, jakie my dyktujemy. Idol chce zatrzymać odblask boskości na tym, co widzialne i co na miarę wzroku, i przechować ją - w sztuce? w pojęciu? - po to, żeby za ich pośrednictwem zapewnić sobie obcowanie z tym, co Transcendentne. Idol to fałszywy bóg, to ubóstwienie tego, co za Boga się podaje, co chce wejść na jego miejsce.

Alternatywą dla idola jest ikona. W niej boskość jest także poniekąd „widziana”, ale w jakże inny sposób! Jaki? W ikonie wzrok nie może „odpocząć”, nie pozwala się uwikłać w urodę rzeczy, lecz jest wciąż

\footnotetext{
3 J.-L. M a ri o n, L'idole et la distance, Paris 1977, s. 23.
} 
porywany od tego, co widzialne ku temu, co niewidzialne. Jest tak, jakby intencja wzrokowa nie wychodziła od nas, lecz od samej boskości, która niewidzialna zdaje się szukać tego, co widzialne, by w nim zamieszkać. W ten sposób ikona wciąż przypomina o tym, co niewidzialne, paradoksalnie czyniąc widzialną niewidzialność jako taką, bezwzględną niewidzialność boskości. Jednocześnie to, co niewidzialne patrzy na nas przez twarz: ,ikona odsłania się jako twarz, która spogląda na nasze spojrzenia, by wezwać je ku swej głębi"4. Oznacza to, że ikona prezentuje nam to, co osobowe i duchowe, bo tylko osoba ma tę zdolność uwidaczniania, przez sam wzrok skierowany na nas, niewidzialnej ku nam zwróconej intencji. Opozycja między idolem a ikoną rysuje się więc wyraźnie: „W idolu spojrzenie człowieka zastyga w swoim zwierciadle, w ikonie spojrzenie człowieka ginie w niewidzialnym spojrzeniu, które zwraca ku niemu widzialna twarz"5. Patrzeć na świat w sposób ikoniczny to widzieć to, co widzialne jako przezroczyste względem tego, co Niewidzialne. Fenomeny idola i ikony, starannie zanalizowane, kierowane są u Mariona wyraźnym założeniem: że idolem może być nie tylko rzecz, ale także pojęcie. Marion podejrzewa bowiem, że „zaćmienie Boga” czy, więcej nawet, „śmierć Boga” ma w dużej mierze swoje korzenie w idolatryzacji pojęć Boga, w szczególności tych, które wiążą Go z losami pojęcia bytu. Problem, który stawia Marion, jest więc następujący: czy pojęcia Boga muszą być idolatryczne, czy też jest możliwe wypracowanie pojęć Boga ikonicznych? Pojęcia takie musiałyby oddawać sprawiedliwość tej szczególnej, właśnie ikonicznej relacji równocześnie dystansu i bliskości, jakiej niedościgłym znakiem, a może wręcz wcieleniem, jest relacja Chrystusa do Ojca. Ikona jest bowiem z istoty teologiczna, a teologia - ikoniczna. Tylko ikona nie zamyka Niewidzialnego w widzialnym, lecz odwrotnie, na Niego otwiera.

\section{Bóg ontoteologii i ekran bycia}

Bóg bywa w filozofii nazywany wieloma imionami: Dobrem, myślącą siebie Myślą, Jednią, Fundamentem (moralnym) świata, Bytem wreszcie. Pytanie, które stawia tu Marion, dotyka od razu zagadnienia central-

4 J.-L. M a ri o n, Bóg bez bycia, przeł. M. Frankiewicz, Kraków 1996, s. 42.

5 Tamże, s. 43. 
nego: co i kto uprawnia do identyfikacji tych pojęć z Bogiem? Święty Tomasz np. pisze na zakończenie każdej ze swych słynnych pięciu dróg, że „wszyscy nazywają Bogiem”: pierwszego poruszyciela, pierwszą przyczyną sprawcza, byt konieczny, przyczynę doskonałości i celowości. Kto to są ci ,wszyscy”? I czy ewentualny „konsens” może być tu zarazem źródłem prawomocności? Niebawem zamiast owych wszystkich pojawią się indywidualne definicje nominalne w rodzaju: ,poprzez Boga rozumiem...", jakie stosowali Descartes czy Spinoza. W rezultacie Bóg staje się igraszką w ręku beztroskich filozofów, którzy nie wahają się utożsamiać Boga z rozmaitymi, własnego pomysłu ideami, a w końcu i przede wszystkim po prostu z naturą ludzka, taki przecież wniosek wyprowadził z Hegla Feuerbach! Jednak dla Mariona pojęciem idolatrycznym par excellence jest pojęcie bytu, a nawet więcej: bycia, a zatem także wykrytej przez Heideggera „różnicy ontologicznej” między bytem a byciem.

Znana jest powszechnie heideggerowska krytyka metafizyki jako „ontoteologii”, którą Marion powtarza bez cienia wahania. U źródeł metafizyki stoi wydarzenie „bycia” - tajemniczego sensu, który objawił się człowiekowi zachodniemu u zarania naszych dziejów i może także świadomości dziejów w ogóle. „Sens bycia” rysuje się jednak od początku jedynie wewnattrz ,gry” bycia i bytu, tzn. tego, co „ma” bycie, co przez nie określone: nie samego „być”, a tego, co ,jest”. Specyfika metafizyki polegała, według Heideggera, na tym, że ,zapomniała” o byciu na rzecz bytu, ale nie byle jakiego, lecz Bytu Najwyższego - Boga. Stało się tak - pisze Heidegger w Identität und Differenz - ponieważ bycie objawiło się człowiekowi od początku w perspektywie, kuszącej i dwuznacznej, „logosu” jako racjonalnego fundamentu, „racji dostatecznej”. Kuszącej i dwuznacznej, bowiem obiecującej czy sugerującej pełną zrozumiałość rzeczywistości, ofiarowującej się ludzkim apetytom poznawczym. Bycie - jako ostateczny fundament - to właśnie Bóg metafizyki jako „ontoteologii”, wiążącej bycie i Boga nierozdzielnym uściskiem. Otóż już dla Heideggera ten Bóg to klasyczny idol, w którym nie sposób odnaleźć Boga religii, Boga prawdziwie boskiego: „Do tego Boga człowiek nie może ani się modlić, ani mu się ofiarować. Przed Causa sui nie może człowiek ani paść na kolana, ani przed takim Bogiem muzykować i tańczyć”" Dla Heideggera jednak ewentualny powrót do ,zagubionego

${ }^{6}$ M. H e i d e g g e r, Identität und Differenz, Pfullingen 1957, s. 64. 
wymiaru" boskości może się dokonać jedynie przez cierpliwe uwalnianie bycia z jego zapomnienia i jego teologicznych serwitutów:

Jakże człowiek naszych czasów może pytać szczerze i rygorystycznie o to, czy Bóg przybliża się czy oddala, jeśli zaniedbuje wmyślenia się w wymiar, w którym tylko to pytanie może być postawione? Ten zaś wymiar jest wymiarem świętości. Pozostaje on, nawet jako wymiar, zamknięty, jeśli otwartość bycia nie prześwituje i w swym prześwicie nie stoi w pobliżu człowieka?

Póki to nie nastąpi, musimy zgodzić się na brak Boga, nihilizm oznaczający, że ,żaden Bóg nie skupia już na sobie ludzi i rzeczy w sposób oczywisty i jednoznaczny i nie składa już, takim skupianiem, dziejów świata, pozwalając w nich przebywać ludziom"s.

Drogi Heideggera i Mariona, wspólne w krytyce ontoteologii, rozchodzą się w odpowiedzi na pytanie: co dalej? Heidegger nie ma wątpliwości, że droga ratunku przed nihilizmem prowadzi poprzez medytację nad samym byciem, jego zapomnieniem i zarazem udzielaniem się człowiekowi: trzeba jakoś odnajdywać na nowo tajemnicę bycia i zarazem blask rzeczy z piętnem świętości. Dla Mariona jest to jedynie najbardziej subtelna i z Jego powodu najgroźniejsza forma idolatrii. Dlatego przeprowadza zasadniczą i wielostopniową rozprawę z filozofią Heideggera, a przez tę krytykę - z kategorią bycia.

Jakie jest - jeśli jest - miejsce dla Boga w filozofii Heideggera? Dwojakie ${ }^{9}$. Najpierw, we wczesnej rozprawie Fenomenologia i teologia, Heidegger przypisuje tę ostatnią szczególnemu sposobowi bycia ludzkiej egzystencji - Dasein - skierowanemu na Boga wiary chrześcijańskiej i na „głupstwo krzyża”! Jednak sposoby bycia - to, co „ontyczne” - zakłada to, co „ontologiczne”, tzn. ogólne struktury bycia, „egzystencjały” Dasein, który przez wszystkie swoje sposoby bycia odnosi się rozumiejąco do bycia po prostu jako do „obiektu” swojej najgłębszej troski: Dasein „chodzi” o bycie. Znaczy to, że bycie jest dla Dasein w istocie od Boga ważniejsze, bo bardziej podstawowe. Jest ono obiektem poszukiwania filozoficznego,

${ }^{7}$ M. H e i d e g g e r, List o humanizmie, przeł. J. Tischner, [w:] t e n ż e, Znaki drogi, Warszawa 1995, s. 159.

${ }^{8}$ M. He i d e g g e r, Cóż po poecie (ze zbioru Holzwege), przeł. K. Wolicki, [w:] t e n ż e, Budować, mieszkać, myśleć, Warszawa 1977, s. 168.

9 J.-L. M a ri o n, Bóg bez bycia, s. 66-112. 
o którym się mówi, że jako neutralne ,poszukiwanie filozoficzne jest i pozostaje ateizmem”, wyrastając z ,egzystencji filozoficznej”, będącej dla wiary konkurencją i dlatego ,śmiertelnym wrogiem”. W tej perspektywie widać jasno, że Bóg wiary (czy filozofii wiary) musi być w myśli Heideggera podporządkowany temu, co dla niego wcześniejsze w porządku warunków możliwości i co równocześnie nie znajduje jakby dla Boga miejsca. Znaczy to, że Bogu stawia się warunki ze względu na to, co dla człowieka ważniejsze, że podporządkowuje się go de facto człowiekowi.

Bóg pojawia się także w filozofii późniejszej jako sfera „bogów” odniesiona do trzech pozostałych sfer w ramach "Czworoboku” (das Geviert), który artykułuje bycie jako pewne uniwersum symboliczne. Ta archaizująca, choć sugestywna wizja, w której to, co boskie wiąże się z tym, co ludzkie oraz z niebem i ziemia, podporządkowuje jednak wyraźnie te cztery ,żywioły” pewnej całości, jaką jest bycie. Właśnie ta wizja zaniepokoiła szczególnie Levinasa, który widział w niej słusznie powrót do greckiego i archaicznego pogaństwa, a zarazem wyraz tendencji totalizujących. Dla Mariona wydają się tu ważniejsze inne momenty:

1. Jak była o tym mowa, filozofia jest dla Heideggera $\mathrm{z}$ istoty ,,ateistyczna", tzn. neutralna względem Boga. Jest to możliwe, ponieważ jej obiekt - Dasein - jest w swej istocie odniesiony nie do Boga, lecz do horyzontu bycia: to on, Dasein, jest zatem w swej istocie ateistyczny i dlatego też filozofia musi być taka. Jest więc z góry wątpliwe, czy na tej bazie można zbudować jakąkolwiek filozofię wierzącej egzystencji, pomimo że Heidegger rozróżnia dla porządku teologię filozoficzną od teologii opartej na objawieniu.

2. Bycie jawi się w tej perspektywie jako „ekran” między nami a Bogiem, ekran, któremu Bóg musi być podporządkowany, o ile ma stać się w ogóle dla człowieka zrozumiały. Nawet jeśli wierząca egzystencja nie musi - i nie powinna - traktować Boga jako Byt Najważniejszy, zawsze przecież musi Boga w perspektywie bycia rozumieć. Czy jest to jednak konieczne?

Związek Boga z pojęciem bytu to jeden z najtrwalszych składników filozofii i teologii chrześcijańskiej. Czy jest on jednak uzasadniony? Marion analizuje w tym aspekcie myśl św. Tomasza z Akwinu.

Jak wiadomo, filozofia i teologia św. Tomasza zakotwicza się w tym, co zostało określone jako metafizyka Księgi Wyjścia: ontologicznej interpretacji boskiego „Jestem, który jestem”. Hebrajska formuła ehjeh aszer ehjeh 
nie przesądza, przypomina Marion za innymi badaczami, bynajmniej tej ontologicznej interpretacji; stała się ona możliwa dopiero poprzez greckie ego eimi ho on, co przeszło w łacińskie ego sum qui sum. Dopiero potrzeba było stanowczej polemiki św. Tomasza z tradycją platońską wcieloną w jeden z największych autorytetów chrześcijańskiej myśli: Pseudo-Dionizego, polemiki przeprowadzonej z pozycji arystotelesowskich, by esse (być) stało się najważniejszym imieniem Boga. Gra idzie, jak jeszcze zobaczymy, o pierwszeństwo Dobra lub Bytu, a wolno zapytać: czy nie także o Miłość lub o Byt? Spór ten św. Tomasz rozstrzyga, jak wiadomo, na korzyść bytu w argumentacji klasycznie arystotelesowskiej, powtórzonej przez Awicennę: primum ... quod cadit in imaginatione intellectus est ens, sine quo nihil potest apprehendi ab intellectu, pierwszym, co wpada w intelektualną wyobraźnię, jest byt, bez którego nic nie może być przez intelekt ujmowane ${ }^{10}$. Dla Mariona oznacza to, że św. Tomasz uzależnia Boga od ludzkiego punktu widzenia - widzenia intelektualnego - dokładnie tak jak Heidegger uzależnia Boga od rozumienia bycia przez Dasein. Dlatego rozważanie ,imion Bożych" w Sumie Teologicznej, które powinno ujawnić, które z tych imion jest pierwsze i najwłaściwsze, następuje de facto już po rozstrzygnięciu, że byt jest imieniem pierwszym, a perspektywa bycia - najwłaściwsza, gdyż nieprzekraczalna. Święty Tomasz uważa, podobnie jak Heidegger, że jeśli Bóg ma być w ogóle przez człowieka rozpatrywany, to Bóg musi być - co więcej, być w sposób maksymalny, być czystym istnieniem. W ten sposób zostaje uświęcone ludzkie spojrzenie, a zamiast Boga pojawia się - idol konceptualny. Bóg zostaje podporządkowany „ekranowi bycia”, oznaczającemu nieprzekraczalny horyzont pojawiania się czegokolwiek. Tymczasem - pisze Marion w odniesieniu do Heideggera:

Skąd pochodzi rozstrzygnięcie, że Bóg (którego, jak za chwilę powiemy, pisze Marion, z przekreśleniem, p.m.) ma być bytem, który przejawia się przez Bycie i w zależności od Bycia? [... Czy rozumie się w końcu samo przez się, że biblijne objawienie ani nie wychodzi poza byt przez to, co objawia, ani poza Bycie przez sam charakter objawienia? Kto decyduje, że sposób objawienia, co do którego Biblia podkreśla, iż przemawia ona polimeros kai politropos, wielokrotnie i na różne sposoby $(\mathrm{Hbr} 1,1)$ musi tymczasem hołdować Byciu?"1

Czy nie można mówić o „Bogu bez bycia”?

10 Sent. (Scriptum super Sententias), I, 8, 1 a 3.

11 J.-L. M a ri o n, Bóg bez bycia, s. 109. 
Odpowiedź Mariona na idolatrię bycia jest trojaka. Po pierwsze, buduje Marion fenomenologię i hermeneutykę „obojętności na bycie”. Wchodzą tu w grę analizy nudy czy - na kanwie Księgi Koheleta - melancholii oraz interesujące i zaskakujące lektury fragmentów listów św. Pawła i Ewangelii. Po drugie, konstruuje on pozytywną kontrpropozycję dla horyzontu bycia w postaci innego i inaczej znaczącego horyzontu: dystansu. Po trzecie, szkicuje fenomenologię daru oraz - paralelnie - ludzkiego podmiotu otwartego na dar w postaci apelu. Choć z czysto filozoficznego punktu widzenia aspekt pierwszy jest może najciekawszy, temat ściśle „teologiczny” każe nam zająć się aspektem drugim i - częściowo - trzecim.

\section{Dobro i dystans}

W polemice z metafizyką i Heideggerem Marion wspiera się o inną tradycję, już także w naszych czasach odnowioną przez Levinasa - tradycję platońską. Jest to platonizm chrześcijański, ale nie tyle św. Augustyna, ile Pseudo-Dionizego: to on właśnie jest głównym sojusznikiem Mariona.

Marion bierze bardzo na serio zarówno zdanie Heideggera, jak i Wittgensteina, że o Bogu należałoby dzisiaj milczeć. Niezależnie od inflacji słów w ogóle i od gadulstwa, dzieje filozofii wskazuja, że Bóg filozofów to idol poddany „dziejom bycia”, immanentny światu jak wszystkie idole. Tymczasem - to jest przekonanie Mariona - musi być oddana sprawiedliwość bezwzględnej transcendencji Boga Biblii. W takim jednak razie Bóg musi „opuścić” horyzont bycia, a człowiek stracić pretensje do poznawania i dyskursu o Bogu na podstawie stworzenia. Powinien nawet zdać sobie sprawę, że także nazwa Boga nie wyraża tego, co chce wyrażać i powinna zostać przekreślona: Bóg. Oznacza to dla Mariona konieczność sięgnięcia do tradycji teologii negatywnej i zinterpretowania jej w sposób radykalny. Równocześnie w świetle teologii biblijnej bycie, świat jest darem. Zadaniem filozofa - filozofa „w obrębie samego chrześcijaństwa”, czego się Marion bynajmniej nie wypiera - jest odtąd łączne myślenie daru i niemożliwości poznania oraz wysłowienia „Boga”.

Teologia negatywna najpierw. Jej sens nie polega na tym, że - jak to się dzieje w teologii pozytywnej - na podstawie stworzenia decydujemy się o Bogu zanegować niektóre, zbyt „trywialne” atrybuty (cielesność...), 
pozostawiając inne (np. mądrość, dobroć). Teologia negatywna w obliczu Absolutu rezygnuje całkowicie z własnego osądu, co bardziej, a co mniej przystoi boskości i decyduje się negować atrybuty jako takie aż do najwyższych i najbardziej „,boskich”. Neguje też, jak była mowa, samą nazwę Boga. W ten sposób „negacje o Bogu są prawdziwe, zaś afirmacje zniekształcone". Gdyby na tym jednak poprzestać, mielibyśmy do czynienia z „uczoną niewiedzą,, czyli de facto pewną postacią wiedzy, wiedzy - prawdę mówiąc - ateistycznej. Tymczasem sensem negacji jest oczyszczenie i wydobycie Transcendencji. Neguje ona ,według transcendencji, a nie według niewystarczalności”; neguje zatem nasz język, a nie rzecz sama.. ,Teologia przewyższająca”, która powtarza tylko w superlatywach teologię pozytywna, niczego tu nie rozwiązuje. Jak więc uniknąc Scylii ,eminencji” i Charybdy totalnej ignorancji?

Pseudo-Dionizy wprowadza w tym miejscu pojęcie ,przyczyny”, aitia ponad bytem: ,Aitia, przyczyna bytu wszystkich rzeczy, sama nie będąca, gdyż ponad wszelką bytowością (uzia)". Jak jednak rozumieć wprowadzenie tej kategorii? Oczywiście nie jako wynalezienie uprzywilejowanego określenia: oznacza ona bowiem raczej to, na co nie mamy żadnej nazwy - samą Transcendencję. Aitia to pojęcie aporetyczne czy paradoksalne - takie, o którym nie można ani milczeć, ani mówić. Jej sens - to zarysowanie wymiaru dystansu.

Pojęcie dystansu jest dla Mariona kluczowe. Co o nim można powiedzieć? Spróbujmy ująć w punktach najważniejsze momenty, które dotychczasowa filozofia Mariona wiąże z pojęciem dystansu.

1. Dystans jest wymiarem Absolutu, w tym sensie, że nie możemy nad nim w żaden sposób zapanować, że przekracza i poprzedza każdą możliwą na jego temat wypowiedź - nawet wypowiedź na temat tej uprzedniości. W tym znaczeniu dystans, o ile można o nim w ogóle mówić, jest radykalnie „dany” - to on nas ,ujmuje”, a nie my jego w jakimś akcie naszego transcendowania.

2. „Daność” dystansu oznacza dla Mariona od razu otwarcie przez niego wymiaru daru. Ten dar to wpierw danie nas sobie samym: dystans to wymiar, dzięki któremu konstytuuje się nasza metafizyczna tożsamość wobec Absolutu: jesteśmy sobie dani, a zarazem przecież nie na siebie „,porzuceni”. Jesteśmy, rzec można, „z wnętrza dystansu”.

3. W języku teologii spekulatywnej można by powiedzieć, że dystans określa korelat „ruchu” Absolutu, który wyzuwa się „ekstatycznie” 
z samego siebie, aby człowiek otrzymał siebie z różnicy względem Absolutu: dystans umożliwia człowieka. Dlatego, powiada Marion, dystans powinien być uszanowany i przyjęty, co oznacza zarazem odmowę jego przywłaszczenia przez ludzkie rozumienie. Dystans nie tylko nie może być zrozumiany, ale nie powinien próbować być zrozumiany.

4. Marion wiąże dystans z pojęciem Dobroci, która jest bez wątpienia chrześcijańską odpowiedzią na platońskie Dobro: aitia to Dobroć. Dystans oznacza, że Dobroć jest równie nie do pomyślenia, jak on, co znaczy tu, że jest „hyperboliczna”, transcendentna: transcendencja i Dobroć wzajemnie się interpretują, ale też dlatego nie są żadnymi przedmiotami poznania. „Przyczyna” świata to Dobroć.

5. Dystans - i to jest kluczowe - zapewnia odstęp, w którym doświadczamy miłości: miłość, tak jak dobroć, wymaga dystansu. Jest tak dlatego, że więź miłości (w języku Platona, a zwłaszcza tutaj Marcela: partycypacja) domaga się i wzmacnia w tajemnicy odmienności: potrzeba „przebyć” drogę ode mnie do ciebie, jeśli miłość ma być w ogóle możliwa. Jedynie w perspektywie miłości można zrozumieć, że partycypacja w Bogu nie tylko nie wyklucza, ale wręcz zakłada dystans ,przyczynowości”. Pseudo-Dionizy podkreśla paradoksalność partycypacji. Z jednej strony boskość „chce” być w całości partycypowaną, z drugiej przecież nie ma żadnego kontaktu ani komunii, która by mieszała boskość z tym, co w niej uczestniczy: bowiem partycypacja domaga się transcendencji i ją wzmacnia. W rejestrze poznawczym oznacza to, że objawienie komunikuje nam to, co niemożliwie do pomyślenia i poznania: samą intymność Boga, sam dystans - co można wyrazić słowami św. Jana w III liście: w Chrystusie ciemność pozostaje wewnątrz jasności. Oznacza to także, jak zobaczymy, że uzewnętrznianie się Boga zbiega się z Jego wycofywaniem - jedno jest nie do pomyślenia bez drugiego.

6. Dar jest bezpośredni, ale musi się wyrazić i interpretować przez to, co pośrednie, tzn. też poprzez ciało pośrednika. Właśnie to cielesne pośrednictwo konstytuuje ikonę jako taką. Ten związek ,ikoniczny” pośrednictwa, pośrednictwa osób i tego, co cielesne, z bezpośredniością daru dowodzi, że mamy tu do czynienia z dystansem, który nie obala bynajmniej różnic, lecz włącza je w miłość. Tę podstawową sytuację „ikoniczną” określa Marion terminem dionizjańskim: hierarchia. Hierarchia to łańcuch stworzonych osób, które otrzymując miłość, powinny przekazywać ją dalej; ten łańcuch daru bywa jednak zaburzony przez zło, 
dlatego wspólnota miłości jest zarazem wspólnotą grzechu. Najdoskonalszą ikoną jest Chrystus, który spełniając najpełniej ludzki stosunek do Boga, ujawnia dystans między sobą jako człowiekiem a Ojcem jako boski, gdyż wypływający z miłości i jej się domagający. W takim jednak razie „hierarchia” wchodzi w samo serce Trójcy Świętej, boskości w trzech osobach: gra dystansu występuje tu jeszcze bardziej, a nie mniej niż w stworzeniu. W swoim skrajnym ubóstwie Syn dostaje wszystko od Ojca - sam dar synostwa - a Syn utrzymuje się w swoim synostwie dzięki pozostawaniu w orbicie daru. Syn jest tym, który traci odwiecznie swoje życie dla Ojca i który właśnie z tego powodu nieustannie i odwiecznie odnajduje je jako dar Ojca: to tu właśnie ,śmierć Boga” uzyskuje swoje najgłębsze znaczenie. Zarazem dystans w łonie Trójcy Świętej jednoczy w miłości bardziej niż wszystko inne - dystans miłości jawi się jako głębszy niż dystans śmierci. Tylko w osobie Chrystusa możemy przejść od dystansu trynitarnego do dystansu stworzonej hierarchii, który jest ikoną Trójcy.

7. W jaki sposób w obrębie dystansu funkcjonuje język? W jaki sposób wypowiadać to, co niewysławialne? Jedynie poprzez modlitwę i wielbienie. W stosunku do aitia predykacja jest, jak wiemy, niemożliwa. Aitia jest ,anonimowa”, nie w rozumieniu abstrakcyjności, lecz nieadekwatności nazywającego języka, nadmiaru, nadwyżki znaczenia nad sensem, jak pisze Marion, nadwyżki, która „odbiera nam mowę”. Jednocześnie ów nadmiar wyzwala w nas wielbienie ,przyczyny” jako... które rozpryskuje się, by tak rzec, od razu w wielość ,imion bożych”. Właśnie dlatego, że aitia jest anonimowa, wyzwala nieskończoność wielbienia i w ten sposób dystans, zapewniony w swej nieredukowalności, może być przebiegany w nieskończoności. Anonimowość i polinomia są tu dwoma brzegami tego samego dystansu; jak pisze Pseudo-Dionizy: „[...] Ten, który jest wielbiony wieloma językami i nazywany wieloma imionami, niewypowiedziany i anonimowy, ten który się prezentuje wszystkim i wszyscy mogą go odnaleźć, (a przecież) nieuchwytny, którego żadne badanie nie może wyśledzić"12.

Marion podkreśla, że ,imiona boże” nie mają nic wspólnego z orzecznikami: język wielbienia nie jest językiem prawdy czy fałszu i nie jest ani subiektywny, ani obiektywny - jest językiem wielbienia ze strony wiel-

12 O imionach Bożych, VII, 1, 865, tłum. franc. Mariona. 
biącego, który przemierza dystans w kierunku przyczyny. „Przemierzanie dystansu" - co to takiego? Zarysowanie relacji? Spełnienie czynności? To wszystko i więcej: szczególna ,gra językowa”, w której „hyperbola Dobroci" odsłania się i skrywa zarazem. Tylko w tej postaci nie mamy tu do czynienia z nowym metafizycznym idolem, lecz z narzędziem krytyki wszystkich idoli boskości.

Dystans to swoisty „czwarty wymiar”, wymiar daru. Jeśli chcemy go przybliżyć, musimy skupić się na całkiem swoistej fenomenologii daru.

\section{Fenomenologia daru}

Może się słusznie wydawać, że dotychczasowe analizy mało mają wspólnego z fenomenologią: są to raczej pewne analizy hermeneutyczno-teologiczne czy nawet metafizyczne, o ile oczywiście przyjmiemy - na co Marion zgodziłby się niechętnie - że istnieje także metafizyka agatologiczna (od to agaton, dobro), a nie tylko ontologiczna (od to on, byt). Wraz z filozofią daru wkracza jednak Marion nie tylko w fenomenologię, ale wręcz w filozofię fenomenologii, która okazuje się nieoczekiwanym wstępem do teologii.

Punktem wyjścia tej nowej filozofii jest ta sama konstatacja, która legła u podstaw odrzucenia przez Mariona zarówno ontologii, jak i heideggerowskiej koncepcji „różnicy ontologicznej”. Myślenie ontologiczne zawsze stawia warunki: czy będą to ,pierwsze prawa bytu i myślenia”, czy „warunki możliwości doświadczenia”, czy horyzont bycia - zawsze chce się dotrzeć do czegoś, bez czego wszystko inne byłoby niemożliwe i co dyktuje swoje prawa wszystkiemu, co może się w polu uwagi pojawić. Jednym $\mathrm{z}$ takich warunków jest także metafizyczna zasada racji dostatecznej, zgodnie z którą wszystko musi mieć swoją rację, a w szczególności świat musi mieć swoją Pierwszą Przyczynę w postaci Boga. Jednakże nie jest pewne, że musi, a w każdym razie nie jest to dla współczesnego człowieka oczywiste: już Nietzsche zamiast pytania: „dlaczego jest raczej coś niż nic?”, stawia w istocie, twierdzi Marion, pytanie: „dlaczego raczej racja niż nicość?"13. Metafizyczne zapytywanie jest w gruncie

${ }^{13}$ Métaphysique et phénoménologie: une relève pour la théologie, tekst, o ile mi wiadomo, jeszcze niedrukowany. 
rzeczy jedynie pewnym dziejowym faktem, którego uniwersalność można zakwestionować. Nie wystarczy jednak zadać dwuznaczne w istocie pytanie: „czy Bóg musi być?”, pytanie prowokujące i groźne, póki nie wypracuje się nowoczesnej metody filozofowania, która zdoła „uwolnić” Boga z sieci oplatających Go filozoficznych warunków.

Metodą tą okazuje się fenomenologia. W jaki sposób? Poprzez ,zasadę wszystkich zasad” Husserla. Zasada ta, jak wiadomo, mówi, że „Każda źródłowo prezentująca naoczność jest źródłem prawomocności poznania, że wszystko, co nam się w intuicji źródłowo [...] przedstawia, należy po prostu przyjąć jako to, co się prezentuje, ale także jedynie w tych granicach, w jakich się tu prezentuje"14. Marion uważa, że sam Husserl nie docenił rewolucyjności własnego odkrycia, gdyż uzależnił fenomeny podwójnie: raz od „horyzontu” zarówno czasu, jak i otwartej całości fenomenów - fenomeny muszą się pojawiać wewnątrz pewnego umotywowanego ciagu; po drugie od transcendentalnego ja: fenomeny muszą się ,usprawiedliwić" przed trybunałem ja. Niemniej skoro intuicja jest instancją ostateczną to warunki zostają zastapione przez danie: intuicja tym się odznacza, że „daje” fenomen. Jakie to ma znaczenie? Przede wszystkim dwojakie. Po pierwsze, czymś pierwotnym jest „donacja”, a więc pewien dar, a nie „obiektywny” i „subiektywny” horyzont. Po drugie, intuicja „daje” także podmiot jemu samemu: podmiot nigdy nie przyłapuje siebie na samokonstytucji, lecz siebie już zawsze zastaje: podmiot jawi się sobie jako „fakt”. Partnerem dania jest podmiot ,zaskoczony” (interloqué), a ostatecznie „zagadnięty" (interpelé) podmiot w wezwaniu (sujet en appel). U Husserla jedynym a priori okazuje się źródłowe a posteriori.

Wnioski płynące z tego stanu rzeczy są doprawdy ważne: Bycie nie jest już koniecznie tym, co pierwotne - pierwotna jest „daność” i samoobecność, fenomen. Właśnie dlatego od rzeczywistości ważniejsza jest możliwość: możliwość nowych sensów, tego co nieprzewidziane. Następnie byt to nie to, co ma fundament czy rację, lecz to, co dane, „darowane”. W ten sposób ,ponad bytem” otwiera się możliwość pierwotniejszej sfery, którą można symbolicznie nazwać Dobrem, a bycie uzyskuje perspektywę nowego sensu: donacji, daru.

W odniesieniu do zagadnień teologicznych - a o nie Marionowi przede wszystkim chodzi - oznacza to, że koncepcja Boga jako ostatecz-

${ }^{14}$ A. H u s s e r 1, Idee, przeł. D. Gierulanka, Warszawa 1967, 24, s. 78-79. 
nego fundamentu czy racji dostatecznej przestaje być dla fenomenologii użyteczna. Jeśli intuicja dostarcza nie tylko samego faktu, lecz także prawomocności tego, co dane, dlaczego traktować je jeszcze jako skutek czegoś innego? Czy ,donacja” powinna być tłumaczona na relację przyczynową? ,W stopniu, w jakim jest bycie-danym, fenomen nie ma także swojego «dlaczego» i nie domaga się go bynajmniej”, pisze Marion. Bóg nie może być myślany jako racja i fundament, jeśli jest sam także dany. Ale czy jest dany? Na to pytanie, którego Marion explicite nie stawia, można odpowiedzieć jedynie odpowiedziawszy wpierw na inne pytanie: co znaczy, że Bóg jest (lub nie jest) dany?

Zauważmy najpierw, że choć fenomenologia zajmuje się, jak sama nazwa wskazuje, fenomenami, to przecież restytuuje na swój sposób kantowskie ,idee rozumu”, czyli obiekty metaphysica specialis: świat, duszę - czy także Boga? „Świat” to wszak horyzont odniesień intencjonalnych, w których świadoma egzystencja od zawsze już się porusza. „Dusza” to po prostu podmiot: nie tylko transcendentalne residuum dawnej metafizyki, jak u Husserla i Heideggera, lecz także drugi człowiek, jak u Levinasa, dany pierwotniej ode mnie i którego pierwotność mnie ,ściga”, nie pozwalając się dosięgnąć obiektywizującą myślą. Jak jest jednak z Bogiem?

Dla Husserla Bóg jako ,absolutny transcendens” jest całkowicie wyłączony z badań fenomenologicznych. Z kolei dla Heideggera, jak wiemy, myślany jest w perspektywie metafizyki lub nagiej wiary, oderwanej od filozofii. Czyż jesteśmy zatem skazani na oscylowanie między filozoficznym milczeniem a wiarą bez rozumu? Jeśli zaś przejdziemy na język daru, czy musimy mówić o „donatorze” daru jako o jego przyczynie? W tym punkcie rozważania Mariona wydają się szczególnie interesujące.

Otóż po pierwsze, można by mówić o donatorze jako o przyczynie tylko gdyby się go traktowało także jako byt, wewnątrz rzeczywistości. Tymczasem „donacja” wydaje się wyrastać z przezwyciężenia perspektywy ontologicznej i rozwijać swoją semantykę w zupełnie innym i daleko bogatszym rejestrze. Po drugie, korelatem bycia-danym nie jest figura donatora, lecz samo bycie-danym par excellence. Doskonałość Boga nie polega ani na samowystarczalności, ani na skuteczności, ani na pierwszeństwie, ale na tym, że daje siebie bardziej niż jakikolwiek byt. Fenomenologiczna figura Boga musi być odczytana w perspektywie fenomenu donacji jako takiej. 
1. Bóg jest dany bez obwarowań i restrykcji, całkowicie: Bóg nie daje siebie w takiej czy innej perspektywie, ale absolutnie i bez rezerwy. Odkrywa się on całkowicie i „rozprzestrzenia” czy „rozlewa” jak Dobro Plotyna czy Substancja Spinozy - ale tak, że dając, pozostaje zarazem sobą. „O ile causa sui zamyka się w sobie, o tyle donacja, którą spełnia Bóg może być sobą jedynie będąc w tym, co daje. O ile w metafizyce Bóg działa jedynie dla siebie, o tyle w fenomenologii dokładnie odwrotnie: jedynie nie będąc w sobie". Bóg jest tylko - i aż - darowywaniem jako takim, jest bowiem Miłością.

2. W konsekwencji absolutny sposób obecności wynikający z donacji wypełnia cały horyzont i wszystkie możliwe horyzonty. Właśnie jednak z tego powodu nie ma tu możliwości ukonstytuowania się jakiegokolwiek przedmiotu-substancji. Bóg nie może być myślany na sposób właśnie obecnego bytu! Dlatego też Bóg nie zajmuje żadnej przestrzeni, nie zwraca niczyjej uwagi, nie zatrzymuje niczyjego spojrzenia. Zatem nieobecność i niepoznawalność Boga nie zaprzeczają donacji, ale właśnie potwierdzają jej doskonałość. Bóg jest nie widoczny nie pomimo donacji, lecz właśnie z jej powodu. Gdyby Bóg był widoczny, nie mógłby być Bogiem.

3. W ten sposób donacja par excellence przemienia się w opuszczenie, kenozę. Doskonałe bycie-danym może dlatego nigdy nie zostać rozpoznane i nie uzyskać nigdy statusu fenomenu. Zwykłe fenomeny są $\mathrm{w}$ zasięgu wzroku, podatne na dysponowanie nimi. Tutaj w fenomenie, czyli „Danym” par excellence, niemożliwość dysponowania jest odwrotną stroną opuszczenia: zauważamy przedmiot i możemy dysponować nim, ale nie kryjącym się za nim gestem wspaniałomyślności. Weryfikujemy, to powiada Marion, ile razy zapoznajemy donacje na rzecz darowanej rzeczy. Tutaj, w Bogu, donacja par excellence jest też doskonale ukryta i będąc czystą donacją, wystawia się na całkowite zapoznanie.

Ta „ontologia” (w sensie ingardenowskim) donacji nie jest, spieszy dodać Marion, konstatacją pewnej rzeczywistości, lecz jedynie możliwości: donacja jest „istotą, nie „faktem”. Fenomenologia nie może pójść dalej w tym kierunku. Sam fenomen daru jest jednak przez Mariona wnikliwie w wielu tekstach analizowany, podobnie jak fenomen miłości. Nie sposób tu niestety tych ważnych i interesujących analiz streszczać. Pozostaje jednak nierozstrzygnięte pytanie, do którego Marion coraz częściej wraca, o objawienie i jego fenomenologiczną strukturę. Gdyż koncepcja 
Boga jako dawcy nie jest przecież czystą idea; to, co można by nazwać odsłonięciem Bożego ukrycia, jest wszak najbardziej fundamentalnym założeniem wszelkich religii - czy nie musi być więc możliwe? Jeśli zaś Chrystus stanowi najdoskonalszy wyraz miłosnego dystansu i model boskiej donacji, czyż nie oznacza to, że Bóg w szczególny sposób sam wyszedł z ukrycia; co zakłada, w każdym razie, że mógł to uczynić? W takim razie rejestr teologiczny powinien dać się przełożyć na rejestr ściśle fenomenologiczny.

Czy i jak można podsumować wciąż przecież otwartą fenomenologiczną teologię Mariona?

Przede wszystkim jest to fenomenologia poheideggerowska, co oznacza szczególne rozumienie tego, czym jest fenomen: fenomen to nie to, co się po prostu jawi, co „na powierzchni”, ale to, co właśnie ukryte i co trzeba wydobyć na jaw. „Czym jest to, co musi być nazwane fenomenem w wyróżnionym sensie? [...] Oczywiście to, co się zrazu i zwykle właśnie nie pokazuje, co [...] jest skryte, lecz równocześnie z istoty przysługuje temu, co się zrazu i zwykle pokazuje i to tak, że ustanawia jego sens i podstawę"15. Dla Heideggera fenomenem takim jest bycie, ale już dla Levinasa np. idea Nieskończoności. Dla Mariona fenomenem jest donacja, która „ustanawia sens i podstawę” fenomenu jako takiego głębiej niż czyni to bycie: bycie musi - wiedział już o tym Heidegger - „być” najpierw darem, aby stanowić „podstawę” bytów. Z kolei dar - jak pokazuje Marion - wymaga ze swej strony własnego horyzontu, horyzontu pozaontologicznego, jakim jest dystans.

Fenomenologia Mariona jest więc fenomenologią szczególną, badającą ,struktury” esencjalne, a przecież nie ontologiczne, co więcej: ,z istoty" niepoznawalne i niewysławialne, a jednak dla człowieka kluczowe. Ta rozwijająca się myśl nie bardzo ufa chyba potocznemu doświadczeniu, które było tak ważne dla wczesnej fenomenologii, a także całej jej mutacji francuskiej - pomna może na niechęć do tej kategorii u Levinasa, dla którego doświadczenie jest sposobem, w jaki podmiot wchłania świat w swoją immanencję raczej niż wychodzi z niej ku Innemu. Stąd pewna spekulatywność tej filozofii, a także jej przesycenie analizami hermeneutycznymi. Marion próbuje po Heideggerze i Levinasie „, iść dalej” i budować filozofię Boga odciążonego od ontologicznych, a nawet etycznych

${ }_{15}$ M. Hei d e g g e r, Bycie i czas, s. 50. 
serwitutów. Mówi on dzięki temu i pokazuje coś, co należało powiedzieć i pokazać: że koncepcja Boga zmienia się całkowicie, jeśli w samym jej centrum tkwi miłość Boga do człowieka, dar i łaska. Nie oznacza to nielojalności wobec naszych przecierpianych czasów, lecz próbę nasycenia ich mimo wszystko światłem: ,zaćmienie Boga” to może odwrotna strona daru ludzkiej wolności, która powinna jednak odnaleźć leżący w jej głębi apel oraz - daru bycia, bez którego akceptacji odpowiedź na dar byłaby niemożliwa. Refleksja filozoficzna ma tu pomóc w odnalezieniu sensu podstawowych kategorii myśli chrześcijańskiej i uwolnieniu ich z systemów podejrzeń, w które nie bez złej woli zostały wplątane. Ceną za tę próbę musi być jednak także odważne porzucenie dobrze znanych i zakorzenionych przyzwyczajeń myślowych - może tak, jak Abraham został wezwany do porzucenia ziemi Ur. 